\title{
11. Zika Virus, Global Health Communication, and Dataveillance
}

\author{
Kirsten Ostherr
}

\begin{abstract}
Through analysis of media produced by the World Health Organization (WHO) in response to the Zika virus outbreak of 2016, this chapter demonstrates how distributed digital communication networks such as social media platforms have created significant challenges for the WHO's top-down model of information management. Unlike disease outbreaks of the past, Zika virus media circulated through mobile, social digital networks shaped by invisible algorithms and filter bubbles that helped generate counter narratives opposing the communications of official health organizations. This chapter examines Zika virus media through the analytical frames of datafication, dataveillance, and data-making to explain how diverse sources of information and social contexts of interpretation pose new challenges for global health communications.
\end{abstract}

Keywords: World Health Organization; Zika virus; health communication; datafication; dataveillance; data-making; contagion; social determinants of health; YouTube; WhatsApp; Facebook

\section{Introduction}

In the years immediately following the creation of the World Health Organization (WHO) in 1948, several films were made that presented the aspirations of this new initiative to audiences around the globe. One of those films, The Eternal Fight (United Nations [UN]/WHO, 1948), offered a rhetorically and stylistically sophisticated narrative of humankind's failed efforts to conquer disease through the ages. The story culminates with the creation of the WHO as a turning point in the ongoing battle

Bonah, C. and A. Laukötter (eds.), Body, Capital, and Screens: Visual Media and the Healthy Self in the 2oth Century. Amsterdam: Amsterdam University Press, 2020 DOI 10.5117/9789462988293_CH11 
against infectious diseases worldwide. Through a combination of live-action footage, animation, melodramatic musical score, and booming voice-over, The Eternal Fight dramatizes the global threat posed by highly contagious diseases such as plague and cholera. Using animated world maps, the film pointedly traces the flow of disease from less developed parts of the world to the congested urban centres that facilitate population-scale pandemics. Highlighting the role of global transportation in spreading disease and the role of global communications in halting their spread, The Eternal Fight presents a vision of a technologically mediated planet in need of mastery by the tools of modern surveillance and containment. The film's vision of WHO as the planet's centralized command and control headquarters conveys a tone of benevolent paternalism mixed with imperialist civilizing mission, modified by a somewhat incongruous claim of fraternalism, as the voice-over proclaims, 'All peoples of every race and belief will be helped by doctors from all races and nations. A tremendous movement of world solidarity is now born'.

As an audiovisual expression of the WHO's mission, The Eternal Fight captures the organization's top-down perspective on health promotion and disease eradication. Experts would assemble, analyse problems, identify solutions, and implement them in the field. In cases of sudden outbreaks, health workers would be rapidly dispatched to halt the spread of infection. Local communities would benefit from the expert knowledge made available to their territories, and, once the health problem was contained, the experts would leave. The centralized, hierarchical, and unidirectional model of knowledge dissemination in this film mirrors that of WHO and most large organizations in the post-Second World War era. Just as motion pictures were a closed form of communication that could send a sealed message in one direction to a receptive audience, the WHO was an assembly of health experts who sent professional guidance and relief to hotspots around the world with no possibility of dialogue, debate, or multidirectional exchange.

The principles and aesthetics embedded in The Eternal Fight illuminate the historical specificity of the approaches to health promotion and health communication of the post-war era, while also highlighting the transition from international to global health frameworks for imagining the processes of disease interventions. ${ }^{1}$ By comparing this example to recent media productions by WHO in response to the Zika virus outbreak of 2016, we can see how changes in peer-to-peer connectivity based on distributed digital

1 Brown et al., 'World Health Organization'. See also the contribution by Jean-Paul Gaudillière in this volume. 
communication networks such as social-media platforms have created significant challenges for the WHO's formal, top-down model of information management. The entry of Zika virus into global awareness has been a highly visual and digitally intermediated phenomenon, characterized by both familiar and novel contagion iconography. Unlike disease outbreaks of the past, Zika virus media circulated through mobile, social digital networks shaped by invisible algorithms and filter bubbles that helped generate counternarratives opposing the communications of official health organizations. This chapter examines Zika virus media through the analytical frames of datafication, dataveillance, and data-making to explain how diverse sources of information and social contexts of interpretation pose new challenges for global health communications. The essay explores how datafication and narration of disease outbreaks has changed from the post-Second World War era to the present, with attention to the ways that emerging digital health platforms for health communication give rise to new concerns about the intersections of personal and global health data. These practices of health datafication create new forms of body capital that provide opportunities for alternative collectivities to emerge, while also contributing to the persistence of certain types of post-war subject formations. As an emblematic post-war use of visual material to convey the ideals of the WHO, The Eternal Fight captures a moment in the history of screen-based media that expands from celluloid projections to globally disseminated and increasingly personalized screens. The chapter concludes with a commentary on a short public-service cartoon, Misión Zika (2016), a recent co-production by the Cartoon Network, WHO, Pan American Health Organization (PAHO), and United Nations Children's Emergency Fund (UNICEF) that captures the aesthetic adaptation to digital screen culture of 21st-century health communication.

\section{Health Datafication}

Ordinary citizens around the world have begun to play an important role in collecting data about health and disease. With mobile connectivity around the world averaging 112 per cent (reflecting a total above 100 per cent due to cases of individual ownership of multiple devices), citizens' daily lives have become experiments 'in the wild', whose digital traces offer new kinds of information about human behaviour and exposures outside of the controlled settings of lab-based studies. ${ }^{2}$ Step counters, continuous heart 
rate monitors, sleep trackers, calorie counters, and other types of activity trackers are popular features of wearable devices that are marketed directly to consumers. These devices contribute to a practice known as 'datafication', that is, the conversion of real-world measurements into digital constructions of reality. ${ }^{3}$ Datafication has been further described as the process of 'rendering into data aspects of the world not previously quantified'. ${ }^{4}$ This transformation of existing data into actionable forms generates diverse and unevenly distributed kinds of value for their producers and consumers. ${ }^{5}$ As a result, historian Dan Bouk argues, 'individuals generate many data doubles that are commodified, capitalized, collected, celebrated, and often out of the control of those they represent'. ${ }^{6}$ In this context, we can see health datafication as a new form of body capital that uses new techniques for measuring and counting the behaviours and exposures of daily life, generating novel forms of value when coupled with data analytics, as I will discuss below. In addition, contemporary practices of health datafication occur both within and beyond clinical settings, posing challenges to traditional understandings of agency and ownership of medical data. Consequently, these practices also challenge traditional approaches to health communication.

Current statistics about digital connectivity around the world highlight the globe scale of this phenomenon, illuminating the uneven distribution of datafication, while nonetheless showing annual trends indicating steady growth. As of January 2018, 53 per cent of the earth's human population used the internet, and 68 per cent used mobile devices. ${ }^{7}$ Much of the world is hyper-connected through the mobile web-based devices that are constantly producing digital footprints and creating conditions of possibility for datafication of ever more aspects of daily life, including health datafication. For example, in the Asia-Pacific region, the single largest market for wearables in the world, mobile connectivity is at 102 per cent. ${ }^{8}$ Not surprisingly, internet use globally is growing more slowly than mobile. These newer technologies leapfrog over the old wire and cable infrastructure of the internet to make new kinds of distributed networks of data that, in their untethered mobility, displace older models of state control of disease surveillance. In many lowand middle-income countries, mobile networks create new opportunities for disease surveillance through digital connectivity that previously were 
not possible in the absence of wired telecommunications infrastructures. ${ }^{9}$ While the new paradigm relocates datafication within corporate power structures in many instances, it also remains subject to state control of information and communication. In contrast to lower overall rates and high global variance in internet connectivity, most of the planet is near or above 100 per cent mobile connectivity. ${ }^{10}$

In many parts of the world, at least 50 per cent of the population also uses social media, signalling that this form of communication is neither fully dominant, nor irrelevant as a source of images and narratives about current events, including disease outbreaks. ${ }^{11}$ The most widely used social-media platforms around the world are Facebook, YouTube, WhatsApp, Facebook Messenger, WeChat, Tencent QQ, Instagram, Tumblr, Ozone, Sina Weibo, and Twitter. ${ }^{12}$ As the world becomes increasingly digitally mediated, everything that users do on mobile, social networks becomes part of the process of datafication. Moreover, the vast data sets that are generated from the casual activities of everyday life are being combined with other data sets, and the assembled purchases, travel, communication, geography, banking, and other kinds of data are used to create digital profiles of users that shape the reality reflected back to them online.

The rise of 'user-generated content' (UGC), that is, voluntarily contributed data such as hotel ratings, purchase feedback, or homemade videos from ordinary internet users, has enabled individual citizens' digital footprints to collectively add up to very large, and potentially very valuable data sets. ${ }^{13} \mathrm{As}$ the health relevance of UGC became obvious to researchers and marketers in the early years of the 21st century, incidental data from mapping apps using global positioning systems (GPS), mobile shopping, restaurant reservation, and rating apps, as well as the data from social-media platforms became part of a complex digital-profiling system with significant influence on mobile health communications. ${ }^{14}$ In addition, the growing popularity of wearable health and wellness trackers from Apple, Fitbit, Xiaomi, Garmin, and Huawei (the top five wearables companies worldwide), has created an abundance of user-generated health data. For the year 2017, total wearable device shipments worldwide reached 115.4 million units, up 10.3 per cent from

Wallis et al., 'Integrating mHealth'.

Kemp, 'Digital in 2018', pp. 29, 95.

11 Kemp, 'Digital in 2018', p. 51; World Health Organization, Global Diffusion, p. 127.

12 Kemp, 'Digital in 2018', p. 59. 
the 104.6 million units shipped in $2016 .{ }^{15}$ This means that at least 115 million people were counting steps, checking their heart rates, and tracking other data, in addition to generating a multibillion-dollar industry worldwide. Yet, these devices are consumer products accessible only to those who can afford to purchase them and maintain their functionality through internet access and up-to-date smartphone interfaces. In this way, digital tracking and counting reproduces the uneven global distribution of information, capital, and health training that is present throughout the history of body capital. Importantly, like the incidental health data derived from GPS or social media, user-generated health data are produced, shared, and exploited under poorly defined privacy and ownership policies. ${ }^{16}$ For example, the terms of use for most wearables stipulates that the company can sell the data collected by the device to third parties in the course of business deals. ${ }^{17}$

In terms of implications for public health, these vast data sets are widely seen as providing new sources of insight from exposures 'in the wild', creating possibilities for hypothesizing new kinds of correlations or even causations between behaviours, exposures, and health outcomes. Yet, as the healthcare industry has begun to embrace big data, a problematic adaptation of Ackoff's hierarchy has taken hold: more data equals more knowledge equals better health outcomes. ${ }^{18}$ Ubiquitous environmental and lifestyle data from wearable technologies and mobile apps promise to uncover new indicators of health and illness from outside of traditional clinical settings. But there are many assumptions embedded in this equation. What new kinds of knowledge might these insights reveal, and for whom might they improve outcomes? The novel achievements of user-generated health data rely heavily on participants' willingness to share their data, even when doing so may not serve their own best interests. ${ }^{19}$ The question of who benefits from big health data is therefore entangled with questions about data ownership, sharing, trust, and privacy. Under conditions of health datafication, individuals often produce data without knowing that they are doing so.

Could these new data sources help to address Social Determinants of Health (SDOH)? Public health-orientated researchers have long argued that biomedical constructs must expand to include $\mathrm{SDOH}$ in order to address the complex, multidimensional lived experience of disease rather than the 
narrowly defined pathophysiology of disease. ${ }^{20}$ The World Health Organization defines $\mathrm{SDOH}$ as 'the conditions in which people are born, grow, work, live, and age, and the wider set of forces and systems shaping the conditions of daily life.. ${ }^{21}$ In light of its capacity to shape the conditions of daily life, I would argue that we now need to consider datafication as an element of $\mathrm{SDOH}$, both for those individuals and communities who are considered 'data rich' and those who are considered 'data poor. ${ }^{22}$ Individuals and communities with the resources to engage in self-tracking behaviour that generates large quantities of health data can be considered 'data rich', while those with limited access to tracking devices might be understood as 'data poor'. These definitions must be nuanced, as self-tracking behaviour does not equate to the ability to gain value from that data, and, in some cases, may only result in increased dataveillance. ${ }^{23}$ Similarly, absence of self-tracking does not prevent other forms of dataveillance on those individuals and communities, and the meaning of fainter digital signals emitting from specific groups is not self-evident, particularly for socially marginalized groups. That is, some communities may prefer to leave less 'digital exhaust' in order to evade detection by government and other authorities. ${ }^{24}$ Health datafication as seen through the lens of $\mathrm{SDOH}$ is therefore a complex nexus of power relations. It offers potentially life-saving benefits for patients with chronic diseases, as well as those faced with emerging infectious diseases. At the same time, datafied SDOH can contribute to practices of surveillance and control, while creating opportunities for medico-corporate profit and exploitation. If wearable health technologies capture $\mathrm{SDOH}$, can they democratize access to care? Or will they exacerbate health disparities? Or both?

\section{Visual Iconography of Contagion: Zika Virus}

By examining the visual iconography of Zika virus communications in 2016 in relation to the concept of health datafication, we can see how long-standing

\footnotetext{
20 Dahlgren and Whitehead, Policies and Strategies.

21 World Health Organization, Social Determinants, not paginated [p. 1].

22 boyd and Crawford, 'Critical Questions'.

23 'Dataveillance' is discussed at length below, but the term can be provisionally defined as 'an increasingly preferred way of monitoring citizens through social media and online communication technologies'; Van Dijck, 'Datafication', p. 204, citing Raley, 'Dataveillance and Countervailance'.

24 Zuboff, 'Big Other'; Raley, 'Dataveillance and Countervailance', p. 131, quoting Giddens, Nation-State.
} 
modes of representing contagion intersect with digital network effects, thereby transforming contemporary practices of health communication. A significant feature of this mediascape is the interplay between the content of the images and their modes of transmission. This section will analyse how health datafication in the context of Zika virus has enabled the emergence of powerful counter-narratives to official health communication scripts through reinterpretation of Zika media. Such narratives based on 'alternative facts' have viral transmission capacity that can destabilize traditional knowledge hierarchies in healthcare. ${ }^{25}$

Historical analysis of Zika media provides a contextual framework for understanding the role of visual imagery in shaping ideas about disease. Attention to this domain of meaning-making is critically important in part because it has a long, influential history of reflecting and shaping social norms and reinforcing moralistic attitudes about social responsibility and contagion. ${ }^{26}$ Additional importance derives from the fact that digital media information and communication networks that provide the substrata of datafication are heavily image-based. Indeed, many scholars have argued that the digital age is characterized in part by a shift from text- to image-based forms of communication, though those images of course carry highly significant textual metadata along with them. ${ }^{27}$ Recall that YouTube and Instagram are among the most used social platforms worldwide. ${ }^{28}$

Since the virus came to global public awareness during the lead up to the summer Olympics in Rio de Janeiro, Brazil in 2016, Zika has been a highly visual and digitally intermediated phenomenon, drawing on both familiar and unfamiliar visual iconography that spread rapidly through Brazil's networked population, with its 113 per cent mobile connectivity rate. ${ }^{29}$ Prominent representational tropes with historical antecedents include close-ups of mosquitoes, ${ }^{30}$ global and local maps of contagion (including transmission pathways and localized prevalence), ${ }^{31}$ travel advisories, ${ }^{32}$ health workers in face masks or biohazard space suits spraying for mosquitoes, ${ }^{33}$

Shtulman, 'In Public Understanding'.

Ostherr, Cinematic Prophylaxis.

Baudrillard, Simulacra and Simulation.

Statista, 'Most Popular'.

Kemp, 'Digital in 2018', p. 97.

McNeil, 'Houston Braces'.

BBC Mundo, 'Cómo el virus zika'; World Health Organization, 'History of Zika Virus'.

LaMotte and Goldschmidt, 'CDC Considers'.

3 Upton, 'Scientists Tease out'; Allen, 'Miami Steps Up'. 

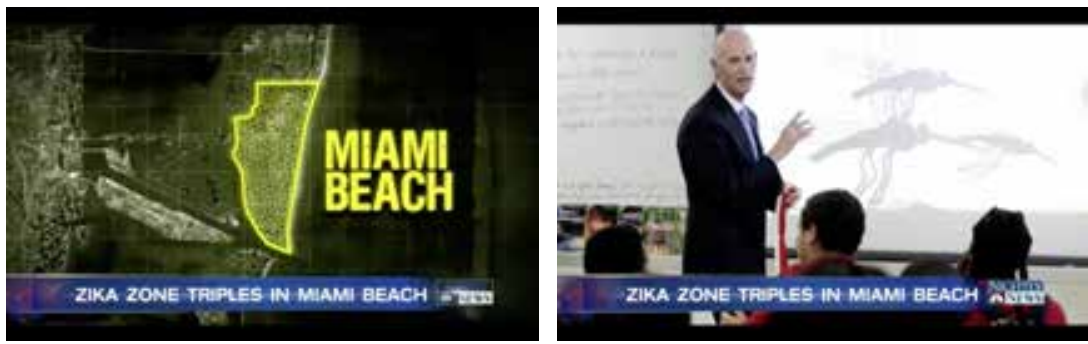

11.1. Two stills from 'Zika Zone Triples in Miami Beach', NBC Nightly News with Lester Holt, 17 September 2016.

aerial spraying by airplanes, ${ }^{34}$ microscopic images of the virus (including computer-generated imagery), and doctors in white coats. ${ }^{35} \mathrm{~A}$ televised segment on NBC News in the United States (29 September 2016) demonstrates the montage techniques historically associated with news reportage of contagion outbreaks. ${ }^{6}$ This brief, 9o-second news segment combines visual images of workers spraying insecticide, maps of transmission zones, close-ups of mosquitoes, Zika testing in laboratories, aerial spraying from airplanes, and anti-insecticide protesters at a city commissioner's meeting, all rapidly edited together, accompanied by a newscaster voice-over. This montage of iconography familiar from past outbreak narratives highlights the extent to which public perceptions of risks from emerging infectious diseases develop according to well-established rhetorical tropes.

New iconography emerging from Zika virus representations include hightech medical imaging of infants and foetuses in utero through computed tomography (CT) scans and sonograms, ${ }^{37}$ photographs of newborn babies with microcephaly, ${ }^{38}$ and images of people in affected areas staring intently at smartphone screens, ${ }^{39}$ their primary source of up-to-date information about the outbreak and risk mediation. The consistency of contagion media over time demonstrates the resilience-or inertia—of official medical media techniques for public communication about disease outbreaks. The militarized 'attack on disease' imagery of the airplanes spraying, the medicalization of the mosquito sprayers, the othering of brown faces, the pathologization of victims, and the world maps using arrows to place blame all resonate with

Belluck, 'Patch of Miami'; Staletovich, 'Air Attack'.

McNeil, 'How the Response'.

36 Holt, 'Zika Zone Triples'.

37 Dana, 'Zika Virus Takes'; McNeil, 'Zika Cases'; McNeil, 'How the Response'.

38 Worth and Osborn, 'How Brazilians Use'; World Health Organization, 'History of Zika Virus'; Firger, 'New Evidence'.

39 Worth and Osborn, 'How Brazilians Use'. 
outbreak media dating to the Second World War and earlier. ${ }^{40}$ All of this iconography can be found in The Eternal Fight, and in many other publichealth films of the post-war era. Yet, when contrasted with the images newly associated with contagion imagery, featuring smartphones and advanced medical imaging technology, we see a conversion of the human, embodied, and social experience of disease into digital formats, rendering a clinical form of health datafication. In addition, the inclusion of footage from protesters points to a new form of contagion iconography that draws from emergent practices of dataveillance. As I will demonstrate below, the intersection of entrenched imagery with new counter-narratives has become a serious liability for health communications efforts in the age of health datafication.

\section{From Surveillance to Dataveillance}

As the practices of global public health become increasingly intermediated with techniques of health datafication, some scholars have argued that the concept of 'surveillance', a fundamental principle of epidemiology, should be reframed as 'dataveillance'. This approach is proposed to better capture how distributed networks of digital sensors and other tracking tools interface with algorithms designed to predict future behaviours and patterns. As Ruckenstein and Schüll have argued, the concept of 'surveillance' can be understood as 'too optically freighted and centrally organized a phenomenon to adequately characterize the networked, continuous tracking of digital information processing and algorithmic analysis' in contemporary practices of dataveillance. ${ }^{41}$ That is, surveillance implies visual observation from above, as exemplified by the legions of closed-circuit television cameras conducting surveillance on the citizens of Beijing, London, and many other world cities. ${ }^{42}$ In contrast, dataveillance emerges from diverse sources, and the resulting information is distributed to multiple interested parties, as in the 'Social Credit System' under development in China that draws from social media, financial records, gaming and entertainment, and other habits. ${ }^{43}$ In the case of health data, sources might include narrowly defined health data as well as all the incidental social, environmental, and behavioural data routinely captured by smartphones and their apps. Dataveillance

Ruckenstein and Schüll, 'Datafication of Health', p. 274.

Lewis, 'You're Being Watched'.

Botsman, 'Big Data Meets'; Raley, 'Dataveillance and Countervailance'. 
highlights the fact that practices of datafication are always running in the background of technologically mediated life in the 21st century, scooping up the traces of users' online, mobile interactions. Importantly, the robust global data brokering economy ensures that any number of entities can observe our digital habits and exert invisible forms of algorithmic control, regardless of which entity originally captured the data.

In addition to the decentralized and distributed forms of power expressed through dataveillance, the predictive orientation of digital 'tracking' practices signal an important shift for several scholars. ${ }^{44}$ When used by digital health companies whose apps provide personal monitoring and control of chronic disease, these patterns can be understood as the datafication of Social Determinants of Health. ${ }^{45}$ The case for updating the concept of 'surveillance' with 'dataveillance' is compelling, particularly in light of the growing role of digital profiling in healthcare and other sectors. ${ }^{46}$ However, it is worth noting that the aim of epidemiological surveillance has long included pattern detection and prediction in order to halt or prevent the spread of diseases, and that practice has long used both visual and non-visual technologies of surveillance. ${ }^{47}$ That is, the critique of surveillance as overly focussed on visual monitoring to observe events as they occur does not fully account for the more precise definition of disease surveillance as practised in public-health fieldwork, where, at present, older practices of surveillance and newer techniques of dataveillance are deeply intermediated..$^{4}$

Therefore, while the critique of surveillance may have limited use in illuminating the applied practice of disease surveillance, the concept of dataveillance is broadly useful for analysing challenges in global health communication today. For example, the concept of dataveillance describes the work of doctors in Brazil who used the decentralized, unofficial WhatsApp network to share their findings and suspicions across diverse field sites to collectively identify the Zika virus outbreak. ${ }^{49}$ Significantly, while those doctors were already discussing Zika in August of 2015, the Pernambuco State Secretariat of Health (an epicentre of the outbreak in Brazil) did not learn of their discoveries until two months later, in mid October..$^{50}$ By using

44 Ruckenstein and Schüll, 'Datafication of Health'; McQuillan, 'Algorithmic Paranoia'; Van Dijck, 'Datafication'.

45 Mason, 'Dear Silicon Valley'.

46 Ostherr, 'Risk Media in Medicine'.

47 Rothman et al., Modern Epidemiology.

48 Propeller Health, 'Outcomes'.

49 Worth and Osborn, 'How Brazilians Use'.

50 Worth and Osborn, 'How Brazilians Use'. 
a service like WhatsApp, with no gatekeeper and no search function, these new, distributed forms of knowledge creation and dissemination circumvent the official, top-down, centralized command-and-control channels of health communication of the past. They are impossible to monitor, and therefore, whether intentionally or accidentally, they create alternate forms of sociality that challenge the authority of traditional forms of medical media expertise.

Moreover, because WhatsApp is used by 87 per cent of doctors in Brazil, and a similar messaging service-WeChat-is used by $5^{\circ}$ per cent of doctors in China to communicate with their patients, the disruptive potential of this new form of health communication is significant. ${ }^{11}$ In an effort to push back against their declining authority, the Pernambuco and Recife health departments in Brazil, two of the critical sites in the Zika outbreak, started using WhatsApp networks to send out their official messaging, consisting of traditional public-health posters with awareness and prevention information..$^{2}$ Apart from the novel use of social-media distribution networks, this strategy is otherwise consistent with centralized, top-down health media techniques dating back to the Second World War era that used posters featuring giant images of vectors like mosquitoes, with cartoon imagery instructing recipients how to behave in the face of the emerging epidemic. ${ }^{53}$ The use of social media to distribute one-way messaging demonstrates the health departments' limited acknowledgement of the shifting paradigms of health communication in the digital age. Use of the new platform may have aided in expanding the scope of the audience, yet the monologic communication strategy of health posters suggests that the 'social' part of the novel approach was underutilized.

Some participants in the Quantified Self and e-patient movements seek to transform the processes of dataveillance and health datafication into a process of health 'data-making' that generates value for the individuals whose bodies generate the data, rather than solely for the corporations who manufacture those devices or provide formal healthcare services to those bodies. ${ }^{54}$ It is unclear how fully citizens might resist dataveillance under current regimes of corporate and state power that monopolize data-mining practices worldwide. However, several examples emerged at the opposite end of the official health communications spectrum, when WhatsApp Zika virus support groups for mothers of babies with microcephaly emerged

Wieczner, 'Why WhatsApp'.

Worth and Osborn, 'How Brazilians Use'.

Ostherr, Cinematic Prophylaxis.

Pybus et al., 'Hacking the Social Life'. 
across Brazil. Participants in one group created by a mother of two older children with non-Zika related microcephaly described the range of peerto-peer healthcare practices as including emotional support and suggestions for developmentally appropriate toys and exercises for affected babies..$^{55}$ Another group formed among mothers who met in a clinic waiting room. They called themselves 'Super Mães Especiais', or 'Super Special Moms'. Researchers who spoke with group members noted the profound difference between the care that the clinic's medical team could provide, and the social, psychological, and logistical support that only the mothers could offer one another. ${ }^{5}$ In Giddens's and Raley's terms, this activity could be considered as a form of 'countervailance' that contrasts with official forms of medical observation that measured and quantified but provided limited real value to the caregivers.

Clinicians who cared for the babies of the 'Super Mães Especiais' also found that the meta-clinical forms of care provided by the WhatsApp group played a critically important role in ensuring the mothers' sustained engagement in care for their children. ${ }^{57}$ The value of peer-to-peer healthcare in this instance supports the observation of researchers who found a mismatch between the content of official medical communications about Zika virus and the information sought and provided by caregivers. In a study of a live tweetchat hosted by the Centers for Disease Control and Prevention (CDC), Glowacki et al. found that caregivers and health officials were both concerned with information about how to control the spread of Zika, yet they noted that the CDC 'did not appear to respond to concerns about consequences for newborns and pregnant women'. ${ }^{8}$ Instead, the CDC followed the established practice of disseminating educational materials.

Official health organizations have recognized the value of communicating through social-media channels. Indeed, a recent survey found that nearly 80 per cent of responding WHO Member States used social media to share health messages with the public.59 Yet, the approach taken usually follows the top-down model of older health communications media, thereby limiting the effectiveness of the WHO's deployment of social media. While some public-health researchers have recognized that social media plays a critically important role for patients and caregivers beyond providing health 
information during crises, most organizations have not adapted to the novel communicative norms that characterize common practice on these platforms. ${ }^{60}$ In a study of Zika communications on Twitter, Fu et al. found that users clearly indicated their preference for health information generated by other users like them, which Pybus, Coté, and Blanke have called citizen data-making, 'rather than those of the government authorities'. ${ }^{61}$ Glowacki et al. suggested that the CDC's failure to allow the public's interest to direct discussion in their Zika virus tweetchat may have been a deliberate tactic to redirect the conversation away from 'fear-ridden tweets' ${ }^{62}$ Yet, in the age of dataveillance, authoritarian control over communications during infectious disease outbreaks only fuels scepticism about health officials' trustworthiness.

As described above, in Brazil, WhatsApp functioned as a digital disease detection and epidemiological surveillance network, and as a social support network. ${ }^{6}$ In what sense might we understand this phenomenon as citizen data-making? Would it be accurate to state that the WhatsApp participants benefitted from big data-driven redefinitions of health and disease? In this instance, does putting health measurement and quantification into the hands of ordinary users become a democratizing force that challenges traditional doctor-patient or state-citizen power and knowledge hierarchies? Alternatively, might health datafication potentially disrupt health infrastructures that citizens have come to depend on? Does it make users vulnerable to third-party exploitation? What factors might tip the scales in one direction or another?

\section{Datafication and Disease Detection}

One method for analysing the effects of datafication and dataveillance on health communications is a media industries approach that analyses financial transactions as critical components of communications infrastructures. ${ }^{64}$ In this context, Facebook's purchase of WhatsApp for US $\$ 19$ billion in October 2014 provides some relevant framing, particularly in light of the company's current use of the messaging app's data to target its

\footnotetext{
6o Lovero and Cardoso, 'Super Special Moms'.

61 Fu et al., 'How People React', p. 1700.

62 Glowacki et al., 'Identifying the Public's Concerns', p. 1711.

63 BBC News, 'Mother Creates'.

64 Parks and Starosielski, Signal Traffic.
} 
advertisements better, and thereby boost profits. ${ }^{65}$ One of the keys to this value stream is Facebook's acquisition of users' phone numbers through their WhatsApp accounts. ${ }^{66}$ This form of corporate integration produces a deep digital intermediation effect, closing loopholes that had previously allowed users to avoid digital profiling based on their activities in social networks. WhatsApp's pre-Facebook terms and conditions promised that it would not share the user's phone number and personally identifiable information for commercial or marketing purposes without their consent. Although users can currently limit some of what Facebook does with their data, the mechanism for doing so is less than obvious and doesn't stop the data going to Facebook. ${ }^{67}$ These practices of cross-platform data integration enable corporate and state powers with access to these data streams to derive value from doctors' networks, mothers of babies with microcephaly, and average citizens seeking health information online. One might argue that the citizens themselves still gain knowledge and, through that, a certain kind of power. But financial profit clearly benefits the corporate entity, not the citizens whose data gives life to the platform.

It is not surprising that Facebook wants to profit from the digital health market; so do Amazon, Google, Apple, Uber, and all of the other major technology companies. ${ }^{68}$ The datafication practice of digitally profiling users through application of analytics to vast data sets of user behavioural data is the primary strategy for both user engagement and financial profit. Microsoft also has a digital health initiative relevant to the Zika case, in its emerging infectious disease dataveillance programme called 'Project Premonition'. The goal of this initiative is 'to detect pathogens before they cause outbreaks - by turning mosquitoes into devices that collect data from animals in the environment'. ${ }^{69}$ The three core components of the project are: 'Find mosquito hotspots by drone', 'Collect mosquitoes with robots', and 'Detect pathogens by gene sequencing'. Project Premonition aims to automate and thereby scale up the efficiencies of human epidemiological surveillance by capitalizing on a wide range of new datafication, dataveillance, and automation techniques. But, at the opposite end of the technology-intensive solutionism spectrum, ${ }^{70}$ a citizen science project in Spain called 'Mosquito Alert' has recently shown that 'citizen science

65 Covert, 'Facebook'; Lomas, 'WhatsApp'.

66 Lomas, 'WhatsApp'.

67 Haselton, 'Facebook's First Response'.

68 Finley, 'Embattled Tech Companies'.

69 Microsoft, 'Project Premonition'.

70 Morozov, To Save Everything. 
costs less than traditional methods and provides early warning information and human-mosquito encounter probabilities of comparable quality with larger geographical coverage'..$^{71}$ Unlike the technology-driven approach represented by Project Premonition, these initiatives show the importance of considering socio-ecological dynamics affecting health outcomes. Citizen science, an approach enabled by the distributed networks of non-expert participants, here demonstrates that mosquito control hinges as much on an understanding of human beings as it does on an understanding of insects.

An app-based public-health initiative called 'Kidenga' was developed at University of Arizona in the United States with a similar goal of engaging children in citizen science vector surveillance. The website notes that the app 'uses an anonymous disease detection map inside of the app and is entirely community-based. $7^{2}$ While promoting the ideals of citizen science, the description of disease detection protocol resonates with dataveillance practices:

Once a week, the Kidenga app will ask you to report whether you are healthy or sick, and mosquito activity near your home. Then visit the app to see other user reports in your area, get the latest news on Zika, dengue, and chikungunya, and learn how to protect yourself, your family, and your community from diseases spread by mosquitoes. Users in Arizona, Texas, and Florida will be able to check which counties in their states have people with Zika. ${ }^{73}$

While Kidenga and Mosquito Alert both use locative technologies to collect their data through mobile media platforms, they reassure participants that their data will be anonymous. However, in light of the widespread digital profiling practices enacted by Facebook and facilitated by WhatsApp data, it is reasonable to question whether the citizens engaged in these efforts are fully aware of the different types of dataveillance they may be enacting, including upon themselves. ${ }^{74}$ Moreover, computer scientist Latanya Sweeney's research group has shown that most mobile apps share data with third parties without users' awareness. ${ }^{75}$ Sweeney has also shown that true anonymization of data is virtually impossible..$^{76}$ Therefore, even 
if Kidenga disease surveillance activities only intend to provide benefits to public health, the project's use of dataveillance techniques potentially puts citizen scientists' data at risk. As this example shows, while citizen science offers a counter-narrative to technological solutionism, these practices are commonly enmeshed in the very practices of datafication they have been created to challenge. Other kinds of digitally intermediated narratives have also emerged from Zika media, particularly in reaction to public concerns about the reach of dataveillance practices. These narratives of conspiracy form the focus of the following section.

\section{Counter-Narratives of Contagion}

Practices of dataveillance generate new types of health data that expand beyond many of the infrastructures and actors traditionally involved in healthcare and health decision-making, opening up the possibility for large-scale counter-narratives to circulate in the same domain as official health communications. Data and practices of datafication have become sites of contestation between government and corporate health agencies and individual citizens. In this context, the use of mobile apps as tools for data collection and research can raise concerns over citizen scientists becoming tools of dataveillance. At the same time, practices of self-quantification may be seen as providing new opportunities for self-care or even self-governance that traditional infrastructures do not provide. The tensions between these models of dataveillance and citizen data-making are evidenced by the hundreds of people protesting in Puerto Rico in July of 2016, after the Centers for Disease Control and Prevention endorsed aerial spraying of the insecticide Naled, which is toxic to bees, birds, and fish. ${ }^{77}$ In this instance, the official narrative that health organizations must spray insecticide to protect the human population was countered by an ecological narrative that linked harms to the environment to harms to human health.

Among publics already accustomed to social-media networks as primary sources of information, epidemiology narratives that include sources, vectors, and patterns of distribution are easily appropriated for alternative purposes. Algorithmic digital profiling creates filter bubbles and feedback loops that reinforce the plausibility of such counter-narratives..$^{78}$ A narrative of epidemiology in the context of health datafication thereby easily becomes 
a narrative of conspiracy, and research has shown that the conspiracy narratives get more 'likes'.79 A group of researchers collected data for one week in June 2016 to determine the most popular videos posted on Facebook related to Zika virus. The researchers classified all videos as either 'relevant' or 'misleading' information or news. ${ }^{80}$ While number of likes or views is an imprecise measure of the impact of the media and the substance of the engagement, the results nonetheless highlight a significant asymmetry of exposure that is consistent with other findings on health communication through social media. ${ }^{81}$

The most popular relevant information post, a World Health Organization press conference by the Emergency Committee on Zika virus, had 43,00o total views. ${ }^{82}$ The full title of the film is WHO-BROLL_-14June 2016: Press Conference after the $3 r d$ Meeting of Emergency Committee on Zika and Observed Increase in Neurological Disorders and Neonatal Malformations. The main presenters, apart from members of the press who appear only briefly on the sidelines of the shot and staffers who are occasionally glimpsed, are Dr. David Heymann, Chair of the Emergency Committee on Zika and Dr. Bruce Aylward, Executive Director ad interim of the Outbreaks and Health Emergencies cluster. The film duration is listed at almost 50 minutes, and the cinematography consists of a single-camera, uncut recording of the two WHO officials presenting the findings of their committee and responding to questions. The film was not edited in post-production and used no music or other special effects, resulting in a dry, scientific, factual presentation of the known facts regarding Zika virus. In contrast to the resources demonstrably invested in The Eternal Fight almost 70 years earlier, the WHO press conference was not staged as a carefully created piece of persuasive media, but rather as a minimalist, emergency communication in response to a global health crisis. The earlier film engaged viewers through images and sounds created by prominent European animation studios, coupled with a narrative built on persuasion, not facts. In contrast, the WHO Zika film presented all of the available scientific evidence, but little by way of persuasion.

The most popular misleading post, a conspiracy film called 10 Shocking Reasons Why Zika Virus Fear Is another Fraudulent Medical Hoax and Vaccine Industry Funding Scam, had 535,00o views. ${ }^{8}{ }^{8}$ The conspiracy film was only

81 Gyenes and Seymour, 'Public Health Echo'.

82 WHO-BROLL.

83 1o Shocking Reasons. 

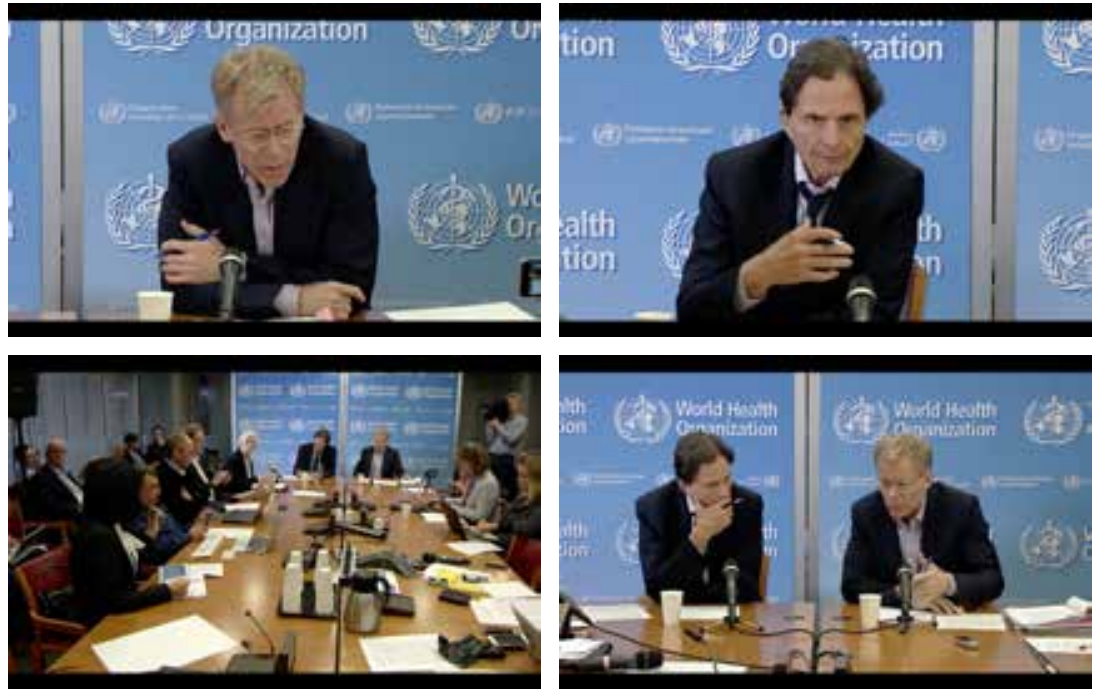

11.2. Four stills from WHO-BROLL-14 June 2016: Press Conference after the 3rd Meeting of Emergency Committee on Zika and Observed Increase in Neurological Disorders and Neonatal Malformations, World Health Organization, 15 June 2016.

two minutes long, and consisted of a rapidly edited montage sequence, accompanied by melodramatic music and sensationalistic intertitles presenting an argument to support the conspiracy theory in the title of the film. The tone of this film was emotional and rhetorical, not scientific and rational. Many of the iconographic images in Zika virus media (close-ups of mosquitoes, babies with microcephaly, aerial spraying from airplanes, maps) were appropriated and reinterpreted in the film to construct a counter-narrative centred on a thesis of media manipulation. The video opens with an enlarged close-up of a mosquito that fills the screen. Cutting to a montage of babies with microcephaly, the film begins its ten-point argument with the first claim, 'The microcephaly cases (shrunken heads) in Brazil were caused by larvicide chemicals, not by Zika'. The second point expands the scope of the conspiracy, stating, 'Even according to the CDC, which is aggressively pushing false Zika fear, nearly all Zika infections are harmless [...]'. Moving deeper into the argument, the next intertitle claims, 'The CDC fabricated the science linking Zika to microcephaly‘. The accusations continue by blaming the US government for removing bans on toxic chemicals and funnelling funds to vaccine manufacturers. The rhetoric escalates to assert, 'Zika virus fear has been used as a weapon of control to terrorize the people of the Americas by violating their private property'. Zika is compared to the great 'bird flu hoax', and depicted as justification for spraying more of the chemicals that 

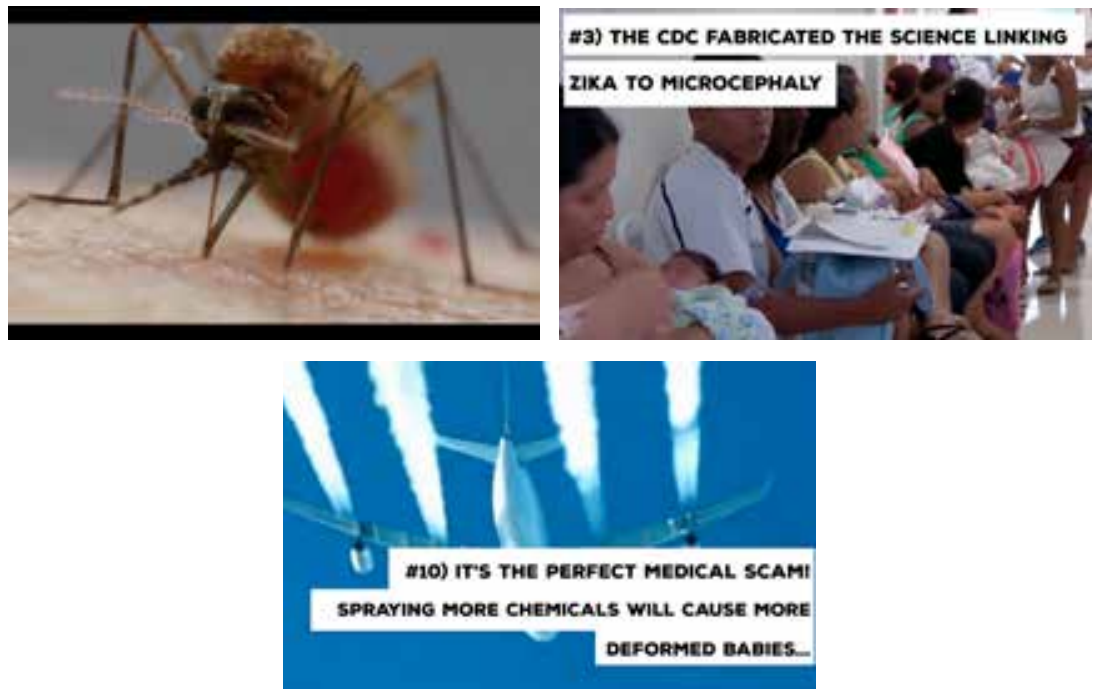

11.3. Three stills from 10 Shocking Reasons Why Zika Virus Fear Is another Fraudulent Medical Hoax and Vaccine Industry Funding Scam, published by Brett Ryan Shaw, 6 September 2016.

the video claims caused the 'shrunken heads' in the first place. Through this rapidly paced and tightly edited montage, the film incriminates the government, the pharmaceutical industry, big agriculture, and medicine as co-conspirators who fabricate scientific evidence for monetary gain.

Comparison of the two films identified by Sharma et al.'s research revealed two contrasting sets of concerns, much as Lovero and Cardoso found in their communications with the 'Super Mães Especiais'. The core concerns of the official health communicators from the WHO were evidence-based, verifiable, and objective information from trusted, authoritative sources (such as governments and non-governmental organizations), disseminated through official channels (such as press releases, public-service announcements, and official news media). In contrast, the health conspiracy theorist was primarily concerned with presenting an emotionally charged narrative that critiqued official discourse from below, disseminated through social media. The misleading post had over ten times as many views as the relevant post. My analysis of the contrasting features of these two popular posts confirms the findings of Gyenes and Seymour, who have argued that 'distinct subcommunities form in digital public health conversations', and, among these sub-communities, public-health organizations are consistently isolated. ${ }^{84}$ The relative unpopularity of the WHO film compared to the conspiracy 


\begin{tabular}{|c|c|c|}
\hline & Epidemiology & Conspiracy theory \\
\hline Sources (characters) & Mosquitoes & $\begin{array}{l}\text { U.S. government/CDC/DOD; } \\
\text { Monsanto; GMO mosquitoes; } \\
\text { Big Pharma }\end{array}$ \\
\hline $\begin{array}{l}\text { Vectors (cause/effect } \\
\text { chains) }\end{array}$ & $\begin{array}{l}\text { Environmental exposure; } \\
\text { sexual transmission }\end{array}$ & $\begin{array}{l}\text { Pesticide spray; vaccine } \\
\text { inoculation; fake blood draws }\end{array}$ \\
\hline $\begin{array}{l}\text { Patterns of distribu- } \\
\text { tion (conflicts \& } \\
\text { resolutions) }\end{array}$ & $\begin{array}{l}\text { Travel to/from 'hot zones', } \\
\text { aedes aegypti zones }\end{array}$ & $\begin{array}{l}\text { Global capitalist cycle of exploi- } \\
\text { tation \& control (sell pesticide } \\
\text { to infect, sell drug to treat) }\end{array}$ \\
\hline Iconography & $\begin{array}{l}\text { Close-ups of mosquitoes; } \\
\text { health workers in space } \\
\text { suits; aerial spraying; maps } \\
\text { of contagion; babies with } \\
\text { microcephaly; microscopic } \\
\text { virus images }\end{array}$ & $\begin{array}{l}\text { Close-ups of mosquitoes; } \\
\text { health workers in space } \\
\text { suits; aerial spraying; maps } \\
\text { of contagion; babies with } \\
\text { microcephaly; microscopic } \\
\text { virus images }\end{array}$ \\
\hline
\end{tabular}

Table 11.1. Features of epidemiology vs. conspiracy theories of Zika virus.

film demonstrates a major challenge of health communication in the digital age: The crowded online environment surfaces sensationalistic emotional appeals more readily than carefully worded scientific statements. The widely noted 'flattening' of hierarchy online undercuts official health organizations' ability to disseminate their messages with unchallenged authority. Unlike the media environment of 1948, when the WHO presented its vision of global disease eradication in The Eternal Fight, the decentralized media networks of the 21st century demand more strategic forms of communication if they hope to gain viewers' attention.

\section{Conclusion}

The growing use of social networks to access news media indicates that more people are receiving information from others in their social-media networks rather than from external, official journalistic news sources. ${ }^{85}$ While social networks can provide valuable sources of peer-to-peer healthcare, scholars have also found that information disseminated through social-media platforms can 'cultivate fear and hasten the spread of misinformation in the face of a public health threat'. ${ }^{86}$ The concurrent rise in the popularity of social video means that the persuasive power of moving images and sound (as distinct from short- or long-form text and still images with captions alone) have the potential 
to enact greater persuasive effects on their networks. ${ }^{87}$ Researchers have also found that the timeliness and immediacy of social-media posts can help to curb fears during disease outbreaks, especially when the public is actively engaged and able to participate fully, not only as a receptacle for official communications. ${ }^{88}$ In light of the need for participatory, image-based public collaboration, health organizations such as WHO and CDC must consider novel approaches to real-time, genuinely social health communications.

To demonstrate the challenge facing official health organizations, I will close with a brief discussion of a short animated public-service announcement called Misión Zika (2016), produced by the Cartoon Network in collaboration with the World Health Organization, the Pan American Health Organization (PAHO), and the United Nations Children's Emergency Fund (UNICEF) during the 2016 Zika outbreak. This public awareness campaign is part of the Cartoon Network's 'Movimiento Cartoon' corporate social responsibility initiative founded in 2010 to promote the well-being of children across Latin America. ${ }^{89}$ The minute-long Misión Zika video was created in Portuguese to be aired in the Brazil market of the Cartoon Network Latin America, where it would reach child viewers. A rapidly edited montage of colourful cartoon superheroes from other programmes on the network such as Powerpuff Girls and Ben 10, the video is framed as a mission briefing that addresses the viewing audience as superheroes in the fight against a supervillain: the mosquito that transmits Zika virus. Purpose-designed visuals of typical mosquito breeding sites such as old tires, flower pots, garbage bins, and water bowls for pets are integrated with shots of the mission director in a high-tech animated environment. Information about how to avoid mosquito bites by wearing long-sleeved shirts and insect repellant also appears on screens in the command centre.

Much like traditional WHO health education films such as The Eternal Fight (1948), Misión Zika transmits instructions from a centralized authority, conveying the expectation that viewers will receive, assimilate, and perform the assigned behaviours. The commander's first appearance on-screen emerges through static as an interruption of regular programming, much like an emergency broadcast. To underscore the urgency of the message, the commander opens by imploring in direct address: 'Calling all superheroes, calling all superheroes! This is not a drill.' He goes on to explain, 'Our communities were invaded by extremely dangerous mosquitoes. We need all

87 McCue, 'Top 10'.

88 Glowacki et al., 'Identifying the Public's Concerns', p. 1709; see also Fu et al., 'How People React'.

89 Restrepo, 'Cartoon Movement'. 

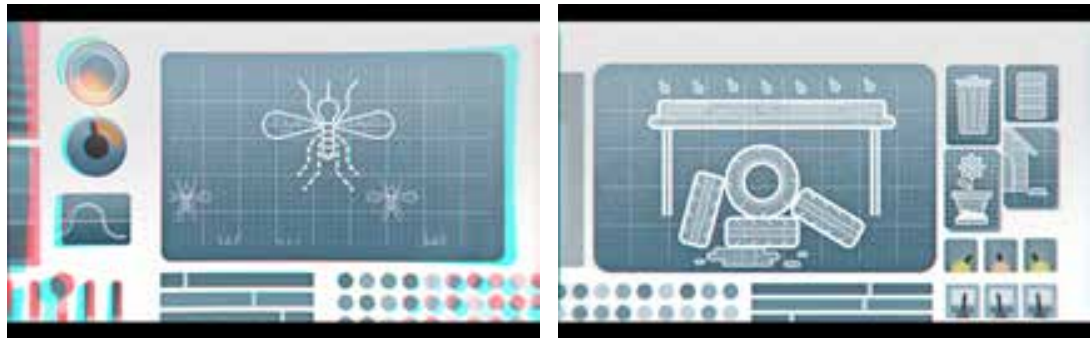

11.4. Two stills from Misión Zika, Cartoon Network/WHO/PAHO/UNICEF, 2016.

the help we can get'. Coupled with visualizations of the command centre as a high-tech room full of screens and control panels, this public-service announcement embraces the surveillance model of health communication. The commander watches the viewers and the mosquitoes, issuing authoritative orders from a centralized locus of information and power.

Though stylistically distinct, The Eternal Fight also used animation to visualize the global spread of contagion and other processes whose scale would otherwise be impossible to represent with conventional photographic film. While the cartoon format in the post-war era and today aims to address the target audience in a style and format consistent with their preferences, this approach is not open to substantive community engagement. The central authority figure issues a command, and viewers may respond through action or inaction, but, in either case, no feedback loop exists to enable direct response to the health communication. In other examples of health dataveillance discussed in this chapter, we can see that new forms of value and power emerge from data-driven practices of monitoring and control. Unlike the distributed mechanisms of dataveillance and the resistant response of citizen data-making, Misión Zika offers an aesthetic update to an otherwise thoroughly outdated model of asynchronous, top-down, remote transmission of expert messaging to a presumably passive viewing audience. The surface appearance has changed, but the core approach remains the same as it was when the WHO was first introduced to the world by The Eternal Fight in 1948.

While the emergent phenomena of datafication, dataveillance, and datamaking raise new computational challenges, they do not eliminate the need for human-centred practices of interpretation and communication, particularly in the context of emerging infectious diseases and other challenges facing global health. If researchers begin to engage concepts like datafication and dataveillance as core elements of a new form of health communication, how then must we change the ways we think about the role of technologies like smartphones and apps in the context of disease communication, monitoring, 
and control? If health datafication is a new Social Determinant of Health, will participation in dataveillance become a predictor of health outcomes? In this emerging mediascape, distributed networks of dataveillance technologies do not necessarily equate to distributed access to power. Perhaps paradoxically, individuals and communities that are not subject to dataveillance may be more vulnerable to health disparities than those who are subject to dataveillance. In response to the manifestly uneven power relations that characterize global digital health economies, counter-narratives migrate online, fuelled by data-driven algorithms and visual iconography that foster suspicion towards official health narratives. While corporate and state techno-paternalism may succeed at data extraction, these systems fail at social engagement, leaving official health organizations to grapple with a distributed communication ecosystem (internet and mobile apps) driven by forces largely invisible to their participants. Meaningful public engagement in health communication will therefore require transparency regarding datafication and dataveillance, coupled with genuine opportunities for citizens to participate in active data-making in response to global health threats to their communities.

\section{Works Cited}

\section{Films, Television Programmes, and Recordings}

10 Shocking Reasons Why Zika Virus Fear Is another Fraudulent Medical Hoax and

Vaccine Industry Funding Scam, published by Brett Ryan Shaw, 6 September 2016, https://www.youtube.com/watch?v=cHfLcEddkHI, accessed on 17 August 2018. The Eternal Fight, photographed and directed by Victor Vicas, United Nations Film

Board/Madeline Carroll Films, 1948.

Misión Zika, Cartoon Network/WHO/PAHO/UNICEF, 2016.

WHO-BROLL-14June 2016: Press Conference after the 3rd Meeting of Emergency Committee on Zika and Observed Increase in Neurological Disorders and Neonatal Malformations, by World Health Organization, 15June 2016, https://www.youtube. com/watch?v=USgp2fNQwR4, accessed on 17 August 2018.

\section{Books and Articles}

Ackoff, Russell L., 'From Data to Wisdom', Journal of Applied Systems Analysis, 16, 1 (1989), pp. 3-9.

Allen, Greg, 'Miami Steps up Mosquito Control Efforts after Suspected Zika Cases', National Public Radio, 22 July 2016, https://www.npr.org/sections/ 
health-shots/2016/07/22/487078904/miami-steps-up-mosquito-control-effortsafter-suspected-zika-cases, accessed 16 August 2018.

Baudrillard, Jean, Simulacra and Simulation, trans. by Sheila Faria Glaser (Ann Arbor: University of Michigan Press, 1994).

BBC Mundo, 'Cómo el virus zika se volvió tan peligroso cuando llegó a América Latina', 27 January 2016, https://www.bbc.com/mundo/noticias/2016/01/160126_ zika_virus_mutacion_america_africa_asia_men, accessed on 16 August 2018.

BBC News, 'Mother Creates WhatsApp Zika Virus Support Group', 27 January 2016, https://www.bbc.com/news/world-latin-america-35414506, accessed 16 August 2018.

Belluck, Pam, 'Patch of Miami Is Ground Zero for the Zika Virus', The New York Times, 8 August 2016, https://www.nytimes.com/2016/o8/og/health/zika-virus-florida. html, accessed 16 August 2018.

Botsman, Rachel, 'Big Data Meets Big Brother as China Moves to Rate its Citizens', Wired, 21 October 2017, https://www.wired.co.uk/article/chinese-governmentsocial-credit-score-privacy-invasion, accessed 16 August 2018.

boyd, danah, and Kate Crawford, 'Critical Questions for Big Data: Provocation for a Cultural, Technological, and Scholarly Phenomen', Information, Communication \& Society, 15, 5 (2012), pp. 662-679, doi:10.1080/1369118X.2012.678878.

Brown, Theodore M., Marcos Cueto, and Elizabeth Fee, 'The World Health Organization and the Transition from International to Global Public Health', American Journal of Public Health, 96, 1 (2006), pp. 62-72, doi:10.2105/AJPH.2004.050831.

Bouk, Dan, 'The History and Political Economy of Personal Data over the Last Two Centuries in Three Acts', Osiris, 32, 1 (2017), pp. 85-106.

Carter, Jamie, 'Why Wearables Have Become Such a Big Deal in Asia', Wareable, 12 May 2017, https://www.wareable.com/wearable-tech/wearables-becominghuge-in-asia-544, accessed 15 August 2018.

Covert, Adrian, 'Facebook Buys WhatsApp for \$19 Billion', CNN Tech, 19 February 2014, https://money.cnn.com/2014/02/19/technology/social/facebookwhatsapp/index.html, accessed 16 August 2018.

Dahlgren, Göran, and Margaret Whitehead, Policies and Strategies to Promote Social Equity in Health:Background Document to WHO-Strategy Paper for Europe (Stockholm: Institute for Futures Studies, 1991).

Dana, Felipe, 'Zika Virus Takes Heartbreaking Toll', CBS News, 28 January 2016, https://www.cbsnews.com/pictures/zika-virus-brazil-heartbreaking-toll/25/, accessed 16 August 2018.

Finley, Klint, 'Embattled Tech Companies Charge Deeper into Health Care', Wired, 1 March 2018, https://www.wired.com/story/embattled-tech-companies-chargedeeper-into-health-care/, accessed 16 August 2018.

Firger, Jessica, 'New Evidence Supports Zika-Microcephaly Connection', Newsweek, 19 February 2016, https://www.newsweek.com/ 
new-evidence-supports-zika-microcephaly-connection-428736, accessed 16 August 2018.

Fu, King-Wa, Hai Liang, Nitin Saroha, Zion Tsz Ho Tse, Patrick Ip, and Isaac Chun-Hai Fung, 'How People React to Zika Virus Outbreaks on Twitter? A Computational Content Analysis', American Journal of Infection Control, 44 (2016), 1700-1702, doi:10.1016/j.ajic.2016.04.253.

Giddens, Anthony, The Nation-State and Violence: Volume 2 of A Contemporary Critique ofHistorical Materialism (Berkeley: University of California Press, 1985). Glowacki, Elizabeth M., Allison J. Lazard, Gary B. Wilcox, Michael Mackert, and Jay M. Bernhardt, 'Identifying the Public's Concerns and the Centers for Disease Control and Prevention's Reactions during a Health Crisis: An Analysis of a Zika Live Twitter Chat', American Journal of Infection Control, 44, 12 (2016), 1709-1711, doi:10.1016/j.ajic.2016.05.025.

Gyenes, Natalie, and Brittany Seymour, 'Public Health Echo Chambers in a Time of Mistrust and Misinformation: Digital Health @ Harvard, February 2017', presentation at Berkman Klein Center for Internet and Society at Harvard University, Cambridge, MA, 23 February 2017, https://cyber.harvard.edu/events/ digitalhealth/2017/02/GyenesSeymour, accessed 17 August 2018.

Haselton, Todd, 'Facebook's First Response to Its Data Leak Scandal Ignores Two of Its Big Products: Instagram and WhatsApp', $C N B C,{ }_{2} 8$ March 2018, https://www. cnbc.com/2018/03/28/facebook-new-privacy-settings-dont-address-instagramwhatsapp.html, accessed on 16 August 2018.

Holt, Lester, 'Zika Zone Triples in Miami Beach', NBC Nightly News with Lester Holt, 17 September 2016, https://www.nbcnews.com/nightly-news/video/zika-transmission-zones-expand-in-miami-beach-767607875611, accessed 16 August 2018. International Data Corporation, 'Global Wearables Market Grows 7.7\% in 4Q17 and 10.3\% in 2017 as Apple Seizes the Leader Position, Says IDC', IDC, 1 March 2018, https:// www.idc.com/getdoc.jsp?containerId=prUS43598218, accessed on ${ }_{15}$ August 2018. Kemp, Simon, 'Digital in 2018: World's Internet Users Pass the 4 Billion Mark', We Are Social, 30 January 2018, https://wearesocial.com/blog/2018/o1/global-digitalreport-2018, accessed 15 August 2018.

Kennedy, Helen, Thomas Poell, and Jose van Dijck, 'Data and Agency', Big Data and Society 2, 2 (2015), pp. 1-7, doi:10.1177/2053951715621569.

Kidenga Team, University of Arizona, The Mel \& Enid Zuckerman College of Public Health, 'Download the Kidenga App!', 2018, https://kidenga.org/, accessed 17 August 2018.

Krumm, John, Nigel Davies, and Chandra Narayanaswami, 'User-Generated Content', IEEE Pervasive Computing, 7, 4 (2008), pp. 10-11, doi:10.1109/MPRV.2008.85. LaMotte, Sandee, and Debra Goldschmidt, 'CDC Considers Travel Warning for Pregnant Women due to Zika Virus', CNN, 15 January 2016, https://edition.cnn. 
com/2016/01/14/health/zika-pandemic-travel-warnings/index.html, accessed 16 August 2018.

Leaf, Clifton, 'The Biggest Share in the Sharing Economy', Fortune, 7 August 2015, https://fortune.com/2015/08/o7/digital-health-data/, accessed 16 August 2018.

Lewis, Paul, 'You're Being Watched: There's One CCTV Camera for Every 32 People in UK', The Guardian, 2 March 2011, https://www.theguardian.com/uk/2011/ mar/o2/cctv-cameras-watching-surveillance, accessed on 16 August 2018.

Lomas, Natasha, 'WhatsApp to Share User Data with Facebook for Ad Targeting-Here's How to Opt Out', TechCrunch, 25 August 2016, https://techcrunch. com/2016/08/25/whatsapp-to-share-user-data-with-facebook-for-ad-targetingheres-how-to-opt-out/, accessed 16 August 2018.

Lovero, Kathryn, and Claudete Araújo Cardoso, "Super Special Moms": Grassroots, Social Media Support Group Aids the Response to Congenital Zika Syndrome', Lancet Global Health Blog, 14 November 2017, https://globalhealth.thelancet. com/2017/11/14/super-special-moms-grassroots-social-media-support-groupaids-response-congenital-zika, accessed 16 August 2018.

Lupton, Deborah, The Quantified Self: A Sociology of Self-Tracking (Cambridge: Polity, 2016).

Mason, Vanessa, 'Dear Silicon Valley, It Pays To Care about Public Health', Fast Company, 3 March 2017, https://www.fastcompany.com/3068726/dear-siliconvalley-it-pays-to-care-about-public-health, accessed 16 August 2018.

Mayer-Schönberger, Viktor, and Kenneth Cukier, Big Data: A Revolution that Will Transform How We Live, Work, and Think (London: Murray, 2013).

McCue, T. J., 'Top 10 Video Marketing Trends And Statistics Roundup 2017', Forbes, 22 September 2017, https://www.forbes.com/sites/tjmccue/2017/o9/22/top10-video-marketing-trends-and-statistics-roundup-2017/\#76 dc51897103, accessed 20 August 2018.

McNeil, Jr., Donald G., 'Houston Braces for Another Brush with the Peril of Zika', The New York Times, 17 July 2017, https:/www.nytimes.com/2017/07/17/health/ zika-virus-houston-texas.html, accessed on 16 August 2018.

McNeil, Jr., Donald G., 'How the Response to Zika Failed Millions', The New York Times, 16 January 2017, https://www.nytimes.com/2017/01/16/health/zika-virusresponse.html?action=click \&contentCollection=health\&module=NextInColle ction \&region=Footer\&pgtype $=$ article $\&$ version $=$ newsevent $\&$ rref $=$ collection $\%$ 2Fnews-event\%2Fzika-virus, accessed 16 August 2018.

McNeil, Jr., Donald G., 'Zika Cases in Puerto Rico Are Skyrocketing', The New York Times, 30 July 2016, https://www.nytimes.com/2016/07/31/health/zika-viruspuerto-rico.html, accessed 16 August 2018.

McQuillan, Dan, 'Algorithmic Paranoia and the Convivial Alternative', Big Data \& Society, 3, 2 (2016), pp. 1-12, doi:10.1177/2053951716671340. 
Microsoft, 'Project Premonition Aims to Detect Pathogens before they Cause Outbreaks', Microsoft, 2 March 2015, https://www.microsoft.com/en-us/research/ project/project-premonition/, accessed 16 August 2018.

Mitchell, Amy, Jeffrey Gottfried, Elisa Shearer, and Kristine Lu, 'How Americans Encounter, Recall and Act Upon Digital News', Pew Research Center, 9 February 2017, https://www.journalism.org/2017/02/o9/how-americans-encounterrecall-and-act-upon-digital-news, accessed 20 August 2018.

Morozov, Evgeny, To Save Everything, Click Here: The Folly of Technological Solutionism (New York: Public Affairs, 2014.)

Neff, Gina, and Dawn Nafus, Self-Tracking (Cambridge: MIT Press, 2016).

Ostherr, Kirsten, Cinematic Prophylaxis: Globalization and Contagion in the Discourse of World Health (Durham, NC: Duke University Press, 2005).

Ostherr, Kirsten, 'Facebook Knows a Ton about Your Health: Now They Want to Make Money Off It', Washington Post, 18 April 2018, https://www.washingtonpost.com/ news/posteverything/wp/2018/04/18/facebook-knows-a-ton-about-your-healthnow-they-want-to-make-money-off-it/?utm_term=.254914aobgbd, accessed on 15 August 2018.

Ostherr, Kirsten, 'Privacy, Data Mining, and Digital Profiling in Online Patient Narratives', Catalyst:Feminism, Theory, Technoscience, 4, 1 (2018), doi:10.28968/ cftt.v4i1.288.

Ostherr, Kirsten, 'Risk Media in Medicine: The Rise of the Metaclinical Health App Ecosystem', in The Routledge Companion to Media and Risk, ed. by Bishnupriya Ghosh and Bhaskar Sarkar (New York: Routledge, in press).

Ostherr, Kirsten, Svetlana Borodina, Rachel Conrad Bracken, Charles Lotterman, Eliot Storer, and Brandon Williams, 'Trust and Privacy in the Context of User-Generated Health Data', Big Data \& Society, 4, 1 (2017), pp. 1-11, doi:10.1177/2053951717704673.

Palmer, John R.B., Aitana Oltra, Francisco Collantes, Juan Antonio Delgado, Javier Lucientes, Sarah Delacour, Mikel Bengoa, Roger Eritja, and Frederic Bartumeus, 'Citizen Science Provides a Reliable and Scalable Tool to Track Disease-Carrying Mosquitoes', Nature Communications, 8, 916 (2017), pp. 1-13, doi:10.1038/s41467-017-00914-9.

Pariser, Eli, The Filter Bubble: What the Internet is Hiding from You (New York: Penguin, 2011).

Parks, Lisa, and Nicole Starosielski, eds., Signal Traffic: Critical Studies of Media Infrastructures (Urbana: University of Illinois Press, 2015).

Propeller Health, 'Outcomes', Propeller Health, no date, https://www.propellerhealth. com/outcome, accessed 16 August 2018.

Pybus, Jennifer, Mark Coté, and Tobias Blanke, 'Hacking the Social Life of Big Data', Big Data \& Society, 2, 2 (2015), pp. 1-10, doi:10.1177/2053951715616649. 
Raley, Rita, 'Dataveillance and Countervailance', in 'Raw Data' Is an Oxymoron, ed. by Lisa Gitelman (Cambridge, MA: MIT Press, 2013), pp. 121-145.

Restrepo, Luis Felipe, 'The Cartoon Movement', Presentation at the Global Child Forum on South America, São Paolo, Brazil, 27 April 2017.

Rothman, Kenneth J., Sander Greenland, and Timothy L. Lash, Modern Epidemiology, 3rd ed. (Philadelphia: Lippincott Williams and Wilkins, 2008).

Ruckenstein, Minna, and Natasha Dow Schüll, 'The Datafication of Health', Annual Review of Anthropology, 46, 1 (2017), pp. 261-278, doi:10.1146/ annurev-anthro-102116-041244.

Sharma, Megha, Kapil Yadav, Nitika Yadav, and Keith C. Ferdinand, 'Zika Virus Pandemic: Analysis of Facebook as a Social Media Health Information Platform', American Journal of Infection Control, 45, 3 (March 2017), pp. 301-302, doi:10.1016/j. ajic.2016.08.022.

Shtulman, Andrew, 'In Public Understanding of Science, Alternative Facts Are the Norm', National Public Radio, 29 May 2017, https://www.npr.org/sections/13.7/2017/05/29/527892222/in-public-understanding-of-science-alternativefacts-are-the-norm, accessed 16 August 2018.

Staletovich, Jenny, 'Air Attack against Zika Hit and Miss in Miami, CDC reports', Miami Herald, 16 August 2016, https://www.miamiherald.com/news/health-care/ article95838697.html, accessed 16 August 2018.

Statista, 'Most Popular Social Networks Worldwide as of April 2018, Ranked by Number of Active Users (in Millions)', Statista, April 2018, https://www.statista. com/statistics/272014/global-social-networks-ranked-by-number-of-users, accessed on May 1, 2018.

Strasser, Bruno J., and Paul N. Edwards, 'Big Data Is the Answer ... But What Is the Question?', Osiris, 32, 1 (2017), pp. 328-345.

Sweeney, Latanya, 'Only You, Your Doctor, and Many Others May Know', Technology Science, 29 September 2015, https://techscience.org/a/2015092903, accessed 17 August 2018.

Upton, John, 'Scientists Tease out Climate Change's Role in Zika Spread', Climate Central, 4 August 2016, https://www.climatecentral.org/news/scientists-teaseout-climate-role-zika-spread-20582, accessed 16 August 2018.

van Dijck, José, 'Datafication, Dataism and Dataveillance: Big Data between Scientific Paradigm and Ideology', Surveillance and Society, 12, 2 (2014), pp. 197-208. van Dijck, José, 'Users Like You? Theorizing Agency in User-Generated Content', Media, Culture \& Society, 31, 1 (2009), pp. 41-58, doi:10.1177/0163443708098245. Wallis, Lee, Paul Blessing, Mohammed Dalwai, and Sang Do Shin, 'Integrating mHealth at Point of Care in Low- and Middle-Income Settings: The System Perspective', Global Health Action, 10, supplement 3 (2017), doi:10.1080/165497 16.2017 .1327686 . 
Wieczner, Jen, 'Why WhatsApp Could Be a Game-Changer for American Health Care', Fortune, 25 August 2016, https://fortune.com/2016/08/25/whatsappencryption-doctors-healthcare-hipaa/, accessed 16 August 2018.

World Health Organization, Global Diffusion of eHealth: Making Universal Health Coverage Achievable: Report of the Third Global Survey on eHealth (Geneva: World Health Organization, 2016), https://apps.who.int/iris/bitstream/hand le/10665/252529/9789241511780-eng.pdf;jsessionid=BEAC2 $\mathrm{CC}_{3} \mathrm{CB}_{708 B F} 392 \mathrm{~A} 2$ 159F4C6D930o?sequence=1, accessed 15 August 2018.

World Health Organization, 'The History of Zika Virus', no date, https://www.who. int/emergencies/zika-virus/timeline/en/, accessed 16 August 2018.

World Health Organization, Social Determinants of Health Unit?, no date, https:// www.who.int/social_determinants/SDH-Brochure-May2017.pdf?ua=1, accessed 16 August 2018.

Worth, Katie, and Catherine Osborn, 'How Brazilians Use WhatsApp to Connect on Zika', PBS Frontline, 23 February 2016, https://www.pbs.org/wgbh/ frontline/article/how-brazilians-use-whatsapp-to-connect-on-zika/, accessed 16 August 2018.

Zang, Jinyan, Krysta Dummit, James Graves, Paul Lisker, and Latanya Sweeney, 'Who Knows What About Me? A Survey of Behind the Scenes Personal Data Sharing to Third Parties by Mobile Apps', Technology Science, 30 October 2015, https://techscience.org/a/2015103001, accessed 17 August 2018.

Zuboff, Shoshana, 'Big Other: Surveillance Capitalism and the Prospects of an Information Civilization', Journal of Information Technology, 30, 1 (2015), pp. 75-89, doi:10.1057/jit.2015.5.

\section{About the Author}

Kirsten Ostherr, PhD, MPH is the Gladys Louise Fox Professor of English at Rice University in Houston, Texas. She is the author of Medical Visions: Producing the Patient through Film, Television and Imaging Technologies (Oxford, 2013) and Cinematic Prophylaxis: Globalization and Contagion in the Discourse of World Health (Duke, 2005). 